\title{
Craniometric measurements and some anatomical characteristics of the cranium in Mediterranean Monk Seal (Monachus monachus, Hermann 1779)
}

\author{
Ahmet ÇAKIR ${ }^{1}$, İsmail Gökçe YILDIRIM ${ }^{2}$, Okan EKİM ${ }^{1}$ \\ ${ }^{1}$ Department of Anatomy, Faculty of Veterinary Medicine, Ankara University, Ankara. ${ }^{2}$ Department of Anatomy, Faculty of \\ Veterinary Medicine, Adnan Menderes University, Aydın, Turkey.
}

\begin{abstract}
Summary: Mediterranean monk seal is one of the endangered species and it is estimated that the total number of this aquatic mammal is less than 600 all over the world. The cranium and the mandible of 2 male and 1 female seals which lived in Turkish coasts and washed ashore as dead were examined morphometrically and macro anatomically. The craniometric measurements were carried out from the reference points. The mean weight of the cranium and the mandible was $1168 \mathrm{~g}$ and mean length of the cranium, from acrocranion to prosthion, was $26.86 \mathrm{~cm}$, mean length of the mandible, from condylar process to cranial part of alveolar (infradental) arch, was measured as $20.03 \mathrm{~cm}$. The aim of this study which included 35 parameters for cranium and 11 parameters for mandible was to reveal the morphometric and certain macroanatomic data concerning the Mediterranean monk seal lived in Turkish coasts and to shed a light to the studies on the endangered species.
\end{abstract}

Keywords: Craniometry, cranium, Mediterranean monk seal, morphometry

\section{Akdeniz Foku (Monachus monachus, Hermann 1779) kafatasının kraniyometrik ölçüleri ve bazı anatomik özellikleri}

Özet: Akdeniz Foku nesli tükenmekte olan hayvanlar arasında bulunan bir deniz memelisidir ve sayısının dünya genelinde 600'den daha az olduğu tahmin edilmektedir. Türkiye kıyılarında yaşamış ve ölü olarak kıyıya vurmuş Akdeniz foklarından 2 erkek, 1 dişi olmak üzere toplam 3 adet ergin hayvanın cranium ve mandibula'ları morfometrik ve makroanatomik olarak değerlendirilmiş ve referans gösterilen noktalardan kafatası ölçümleri alınmıştır. Kafatasının mandibula ile birlikte ortalama ağırlığ 1168 gr, kafatasının ortalama uzunluğu (akrokranion'dan - prosthion'a) 26,86 cm, mandibula uzunluğu da [processus condylaris'ten - arcus alveolaris'in ön ucuna (infradentale)] ortalama 20,03 cm olarak ölçülmüştür. Kafatasında 35, mandibula'da 11 parametrenin alındığ bu çalışmanın amacı, Türkiye kıyılarında yaşayan Akdeniz Foklarının kafatasına ait morfometrik ve bazı makro anatomik bilgileri ortaya koymak, ayrıca nesli tükenmekte olan hayvanlarda yürütülen çalışmalara 1şık tutmaktır.

Anahtar Sözcükler: Akdeniz foku, kafatası, kraniyometri, morfometri

\section{Introduction}

Every passing day changing of environmental conditions and climatic factors cause danger for living things and Mediterranean monk seal is one of the endangered species $(17,23)$. It is estimated that the total number of these aquatic mammals is less than 600 all over the world $(8,19,21)$.

Taxonomically, Mediterranean monk seal belongs to the class of mammalia, phylum of placentalia, order of carnivora, pinnipedia suborder, phocidae family and monachus genus (19). However, this species, "Monachus monachus" by Hermann (1779), is generally known as Mediterranean monk seal, the population split into two principal subpopulations living in the eastern Atlantic and Mediterranean waters $(8,15,16,21)$. The members of this species prefer to live in individuals on the contrary to their relatives (21).

Considering the previous studies, certain characteristics, lifestyles, the territorial zones (1, 2, 3, 5, $7,20)$ and behavior properties $(10,28)$ of the endangered species were studied. Also the morphology of the female genital organs (4), osteoporosis cases (24), calculation of the survival rate based on certain physical features (6), the relationship between mastication and the masticatory muscles (14), infections (29) and computed tomography of the cranium (13) were already researched.

Certain researches can be sited about the biology, status and distribution of the Mediterranean monk seals living on Turkish costs $(17,23,25,26)$. The members of Underwater Research Society (SAD) - Mediterranean 
Seal Research Group (AFAG) regularly continue the scientific researches mainly about those above in monk seals $(17,18,21,22,23)$.

Field studies are generally based on in-situ noninvasive observations of the seals in their natural habitat or in conservation $(8,19,21,22)$. But, the number of quantitative researches about cranium morphometry in monk seals is quite few and studies conducted on morphometrical analyses of the skulls were performed especially on those lived in Adriatic Sea $(15,16)$. The craniometric information about Mediterranean monk seals living on the Turkish coasts is limited or unstated in current articles $(18,22,23,25,26)$.

The cranium bones are examined in two main parts as neurocranial bones (occipital, interparietal, basisphenoid, presphenoid, pterygoid, temporal, parietal, frontal and ethmoid bones) and facial bones (nasal, lacrimal, maxillar, incisive, palatine, zygtomatic bones and the mandible) (12). The anatomy of these structures might probably be varied with the effects of behavior types, feeding habits and other typical characteristics of the species and these variations can present efficient data to the researchers.

The aim of this study was to reveal some anatomical features and measurements of bones that constitute the cranium of monk seal, to give an opportunity for the comparison of the findings with the data obtained in the past and also to shed a light to the studies planned in the future.

\section{Materials and Methods}

The study material was consisted of the cranium and mandible bones as follows; (No 1.) An adult male Mediterranean Monk Seal which was sent to Ankara University Faculty of Veterinary Medicine Department of Anatomy by SAD-AFAG and was found as dead on the Çatalada island Bodrum Turgutreis offshore, (No 2.) an adult male Mediterranean Monk Seal in Adnan Menderes University Faculty of Veterinary Medicine Department of Anatomy, (No 3.) an adult female Mediterranean Monk Seal in Kuşadası Doğanbey National Park Museum. The cranium and mandible sent by SAD-AFAG were macerated. The bones belong to the other two Mediterranean monk seals had been macerated previously. The length measurements belong to three craniums and mandibles and the measurements of the specific structures referenced before (11), were taken by digital calipers and measuring tape. The weight measurements, except the one in the Doğanbey Museum, were taken by assay balance.
Table 1. Measurements of the cranium in Mediterranean monk seal.

Tablo 1. Akdeniz foku'nda cranium'un ölçümleri.

\begin{tabular}{|c|c|c|c|c|}
\hline $\begin{array}{l}\text { Cranial } \\
\text { Measurements }\end{array}$ & No 1 & No2 & No3 & Average \\
\hline 1 & 29.0 & 26.0 & 25.6 & 26.86 \\
\hline 2 & 28.4 & 27.1 & 25.4 & 26.96 \\
\hline 3 & 26.5 & 25.9 & 24.0 & 25.40 \\
\hline 4 & 09.1 & 10.0 & 07.0 & 08.70 \\
\hline 5 & 17.4 & 15.1 & 16.3 & 16.26 \\
\hline 6 & 25.2 & 24.7 & 24.8 & 24.90 \\
\hline 7 & 08.8 & 08.5 & 08.4 & 08.56 \\
\hline 8 & 11.5 & 11.8 & 09.0 & 10.76 \\
\hline 9 & 18.0 & 18.2 & 17.9 & 18.03 \\
\hline 10 & 05.2 & 08.0 & 03.2 & 05.46 \\
\hline 11 & 08.4 & 09.1 & 08.3 & 08.60 \\
\hline 12 & 11.8 & 12.8 & 11.5 & 12.03 \\
\hline 13 & 13.1 & 12.6 & 11.4 & 12.36 \\
\hline 14 & 01.7 & 02.7 & 02.3 & 02.23 \\
\hline 15 & 02.9 & 02.4 & 02.1 & 02.46 \\
\hline 16 & 06.5 & 05.8 & 06.2 & 06.16 \\
\hline 17 & 04.1 & 04.3 & 03.6 & 04.00 \\
\hline 18 & 17.2 & 11.2 & 16.6 & 15.00 \\
\hline 19 & 15.3 & 14.0 & 16.7 & 15.33 \\
\hline 20 & 06.6 & 06.6 & 05.8 & 06.33 \\
\hline 21 & 11.4 & 09.4 & 10.2 & 10.33 \\
\hline 22 & 02.6 & 03.0 & 04.0 & 03.20 \\
\hline 23 & 02.2 & 03.5 & 03.2 & 02.96 \\
\hline 24 & 11.7 & 11.2 & 11.3 & 11.40 \\
\hline 25 & 19.1 & 19.9 & 17.4 & 18.80 \\
\hline 26 & 03.5 & 03.4 & 02.7 & 05.20 \\
\hline 27 & 03.7 & 03.9 & 02.9 & 03.50 \\
\hline 28 & 07.4 & 07.7 & 06.4 & 07.16 \\
\hline 29 & 08.8 & 08.8 & 06.5 & 08.03 \\
\hline 30 & 04.9 & 05.9 & 05.1 & 05.03 \\
\hline 31 & 07.2 & 06.6 & 05.3 & 06.36 \\
\hline 32 & 08.4 & 06.5 & 06.9 & 07.26 \\
\hline 33 & 08.9 & 09.6 & 09.1 & 09.20 \\
\hline 34 & 07.9 & 08.9 & 08.4 & 08.40 \\
\hline 35 & 09.0 & 09.3 & 08.3 & 08.86 \\
\hline
\end{tabular}

Table 2. Measurements of the mandible in Mediterranean monk seal.

Tablo 2. Akdeniz Foku'nda mandibula'nın ölçümleri

\begin{tabular}{lcccc}
\hline $\begin{array}{l}\text { Mandible } \\
\text { Measurements }\end{array}$ & No 1 & No 2 & No 3 & Average \\
\hline 1 & 19.6 & 20.8 & 19.7 & 20.03 \\
2 & 18.3 & 19.1 & 18.3 & 18.50 \\
3 & 18.0 & 18.6 & 18.1 & 18.23 \\
4 & 17.8 & 17.8 & 17.4 & 17.66 \\
5 & 16.4 & 16.6 & 15.9 & 16.30 \\
6 & 16.4 & 16.7 & 15.7 & 16.26 \\
7 & 06.9 & 06.5 & 06.8 & 06.73 \\
8 & 02.1 & 02.3 & 01.7 & 02.03 \\
9 & 08.9 & 06.5 & 07.5 & 07.63 \\
10 & 03.6 & 03.6 & 03.2 & 03.46 \\
11 & 04.1 & 03.8 & 03.3 & 03.73 \\
\hline
\end{tabular}




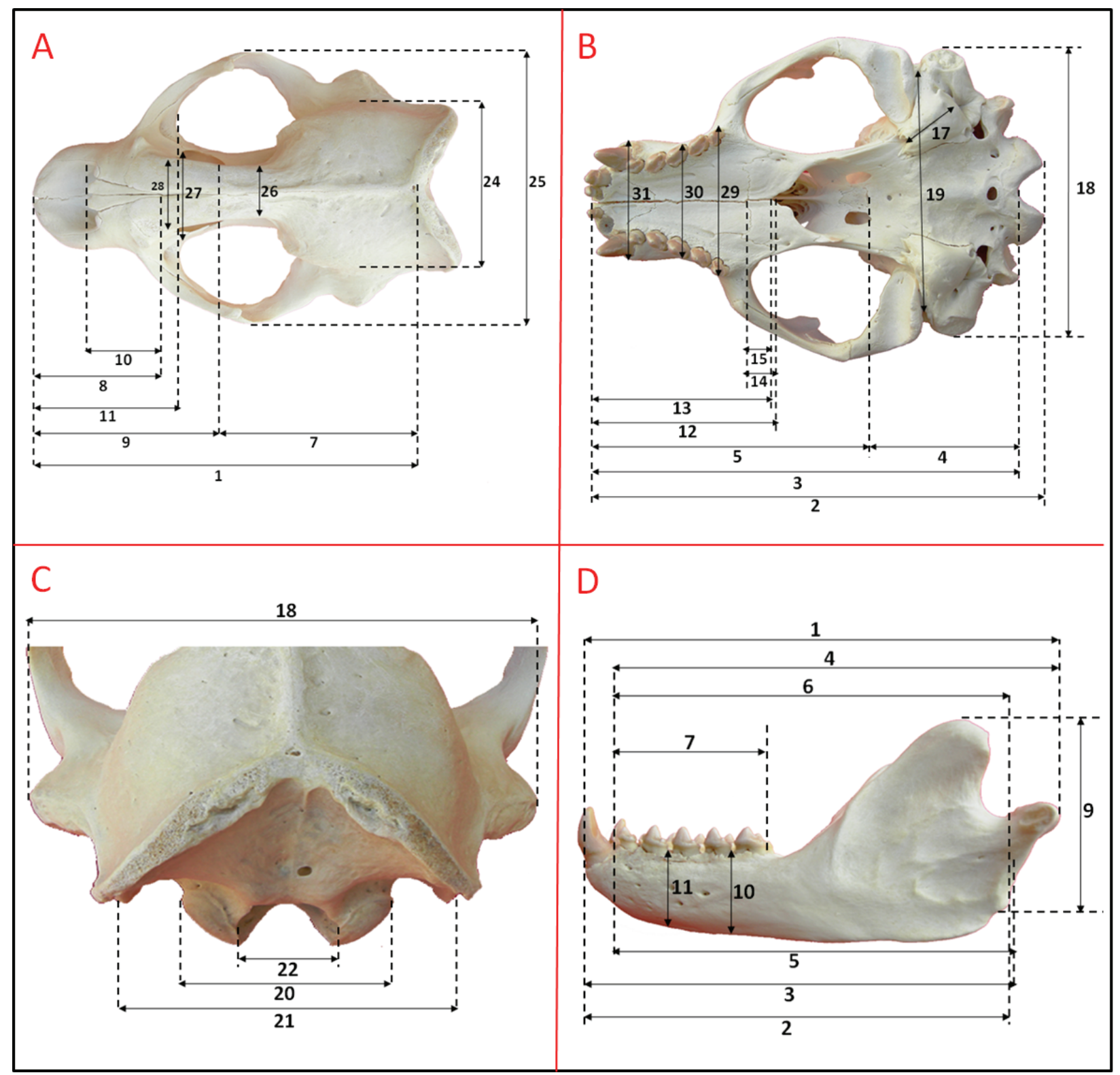

Figure 1. Landmarks for the measurements of the Mediterranean monk seal's cranium (Parameter numbers shown on Figure 1 were detailed in the text), A. Dorsal, B. Basal, C. Occipital aspect, D. Mandible

Şekil 1. Akdeniz Foku cranium'unun ölçümleri için seçilen noktalar (Şekil 1 üzerindeki gösterilen parametre rakamları metinde detaylandırılmıştır), A. Dorsal, B. Basal, C. Occipital görünüm, D. Mandibula.

$\underline{\text { Parameters for the cranium (Figure } 1 . \mathrm{A} ; \mathrm{B} ; \mathrm{C} \text { ) }}$

1. Total length: Acrocranion - prosthion

2. Condylobasal length: Aboral border of the occipital condyles - prosthion

3. Basal length: Basion - prosthion

4. Basicranial axis: Basion - synsphenion (intersphenoid suture)

5. Basifacial axis: Synsphenion - prosthion

6. Neurocranium length: Basion - nasion

7. Upper neurocranium length: Acrocranion - Frontal midpoint

8. Viscerocranium length: Nasion - prosthion

9. Facial length: Frontal midpoint - prosthion

10. Greatest length of the nasals: Nasion - rhinion

11. Snout length: Oral border of the orbits - prosthion
12. Median palatal length: Staphylion - prosthion

13. Palatal length: The median point of intersection of the line joining the deepest indentations of the choanae - prosthion

14. Length of the horizontal part of the palatine: Staphylion - palatinoorale

15. Length of the horizontal part of the palatine corresponding to 13

16. Length of the cheektooth row (measured along the alveoli on the buccal side)

17. Greatest diamater of the auditory bulla: From the most aboral point of the bulla on the suture with the paraoccipital process up to the external carotid foramen 
18. Greatest mastoid breadth = greatest breath of the occipital triangle: Otion - otion

19. Breadth dorsal to the external auditory meatus

20. Greatest breadth of the occipital condyles

21. Greatest breadth of the bases of the paraoccipital processes

22. Greatest breadth of the foramen magnum

23. Height of the foramen magnum: Basion - opisthion

24. Greatest neurocranium (ossa cranii) breadth = greatest breadth of the braincase: Euryon - euryon

25. Zygomatic breadth: Zygion - zygion

26. Least breadth of skull = least breadth aboral of the supraorbital processes

27. Frontal breadth: Ectorbitale - ectorbitale

28. Least breadth between the orbits: Entorbitale entorbitale

29. Greatest palatal breadth: measured across the outher borders of the alveoli

30. Least palatal breadth: measured behind the canines

31. Breadth at the canine alveoli

32. Greatest inner height of the orbit
33. Skull height. The two pointers of the slide gauge are placed basally on the basis of the skull and dorsally on the highest elevation of the sagittal crest

34. Skull height without the sagittal crest. The slide gauge is placed in the same position as for M 33 with the difference that the upper pointer is placed beside the sagittal crest on the highest point of the braincase

35. Height of the occipital triangle: Acrocranion Basion

\section{Parameters for the mandible (Figure 1.D)}

1. Total length: Length from condylar process infradentale

2. Length: The angular process - infradentale

3. Length from the indentation between the condylar process and the angular process - infradentale

4. Length: The condylar process - aboral border of the canine alveolus

5. Length from the indentation between the condylar process and the angular process - aboral border of the canine alveolus

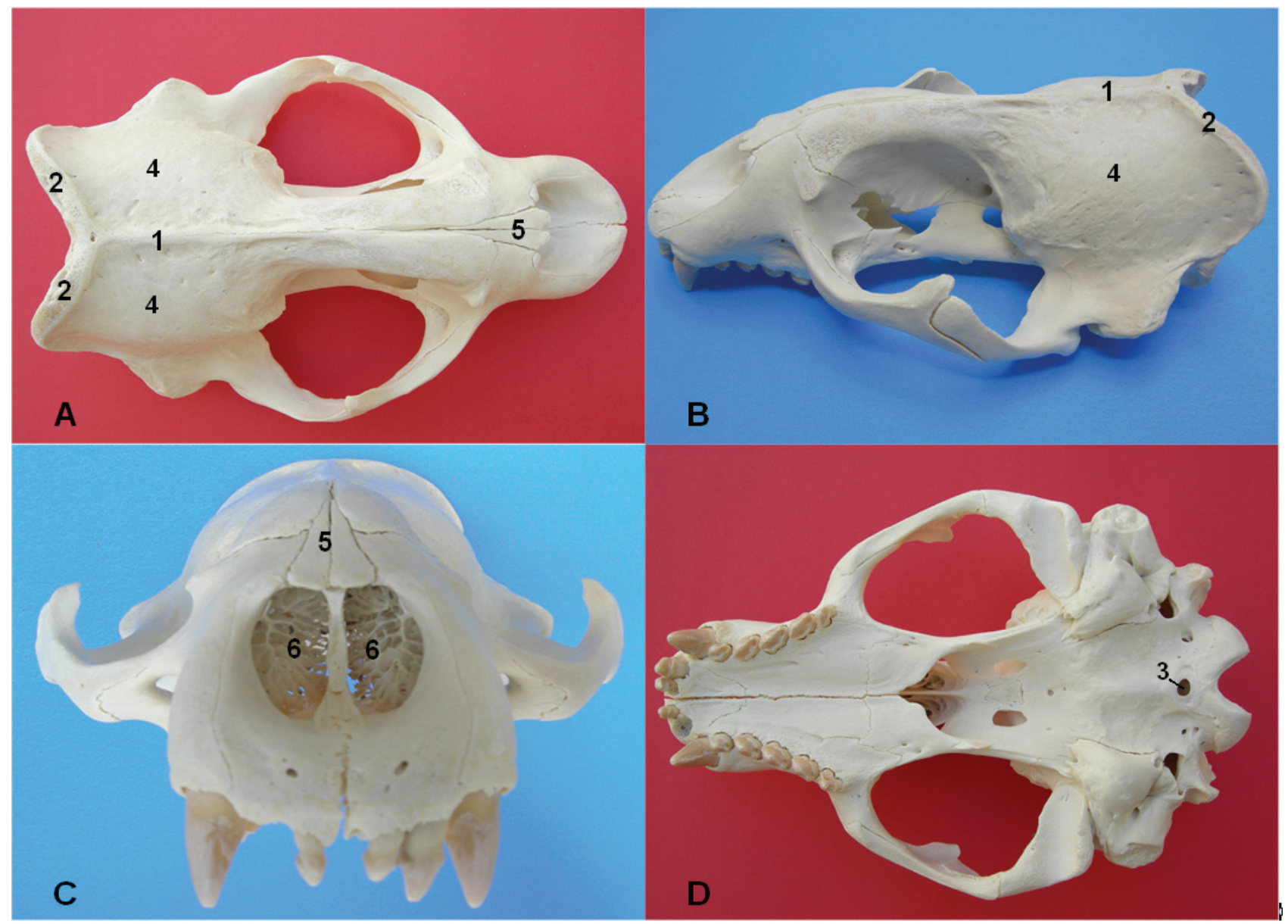

Figure 2. View of the Mediterranean monk seal's cranium, A. Dorsal, B. Lateral, C. Cranial, D. Basal aspect.

1. External sagittal crest, 2. Nuchal crest, 3. Circular hole at the basal part of occipital condyles, 4. Parietal bone, 5. Nasal Bone, 6. Lamina of nasal conchae.

Şekil 2. Akdeniz Foku cranium’unun görünümü, A. Dorsal, B. Lateral, C. Cranial, D. Basal görünüm.

1. Crista sagittalis externa, 2. Crista nuchae, 3. Condylus occipitalis'lerin basal'inde sirküler delik 4. Os parietale, 5. Os nasale, 6. Conchae nasales'e ait lamina. 
6. Length: The angular process - aboral border of the canine alveolus

7. Length: The aboral border of the alveolus of M5 aboral border of the canine alveolus

8. Greatest thickness of the body of jaw (below M1)

9. Height of the vertical ramus: Basal point of the angular process - coronion

10. Height of the mandible behind M1, measured on the lingual side and at right angles to the basal border

11. Height of the mandible between M2 and M3, measured on the lingual side and at right angles to the basal border.

\section{Results}

The weight of the cranium and the mandible of the Mediterranean Monk Seal sent by SAD - AFAG to Ankara was found as $845 \mathrm{~g}$ and $313 \mathrm{~g}$ respectively. When the bones formed the cranium were analyzed, it was observed that the external sagittal crest (Figure 2.A.1; B.1) was not significant. The nuchal crest went through laterally and caudoventrally (Figure 2.A.2; B.2). A circular hole was found close to the foramen magnum at the basilar part of the occipital bone (Figure 2.D.3; Figure 4.B.7). Parietal bone was more protuberant and wide laterally, so cranial cavity took a wide form (Figure 2.A.4; B.4). Frontal bone had neither a frontal fossa nor a zygomatic process. However there were two prominent processes at the back, on the front edge of the parietal bone and at the front between maxillary and the lacrimal border, these structures didn't seem like zygomatic process of the frontal bone. It was determined that the frontal bone was prolonged toward the front; thereby maxilla was short (Figure 3.A.1; B.1; D.1). Orbit was wide. On the medial face of the orbit, there was a considerably wide hole (length $41 \mathrm{~mm}$; width $20 \mathrm{~mm}$ ) with irregular edges like lacerated foramen and it was opened into the nasal cavity (Figure 3.A.2; B.2; D.2).

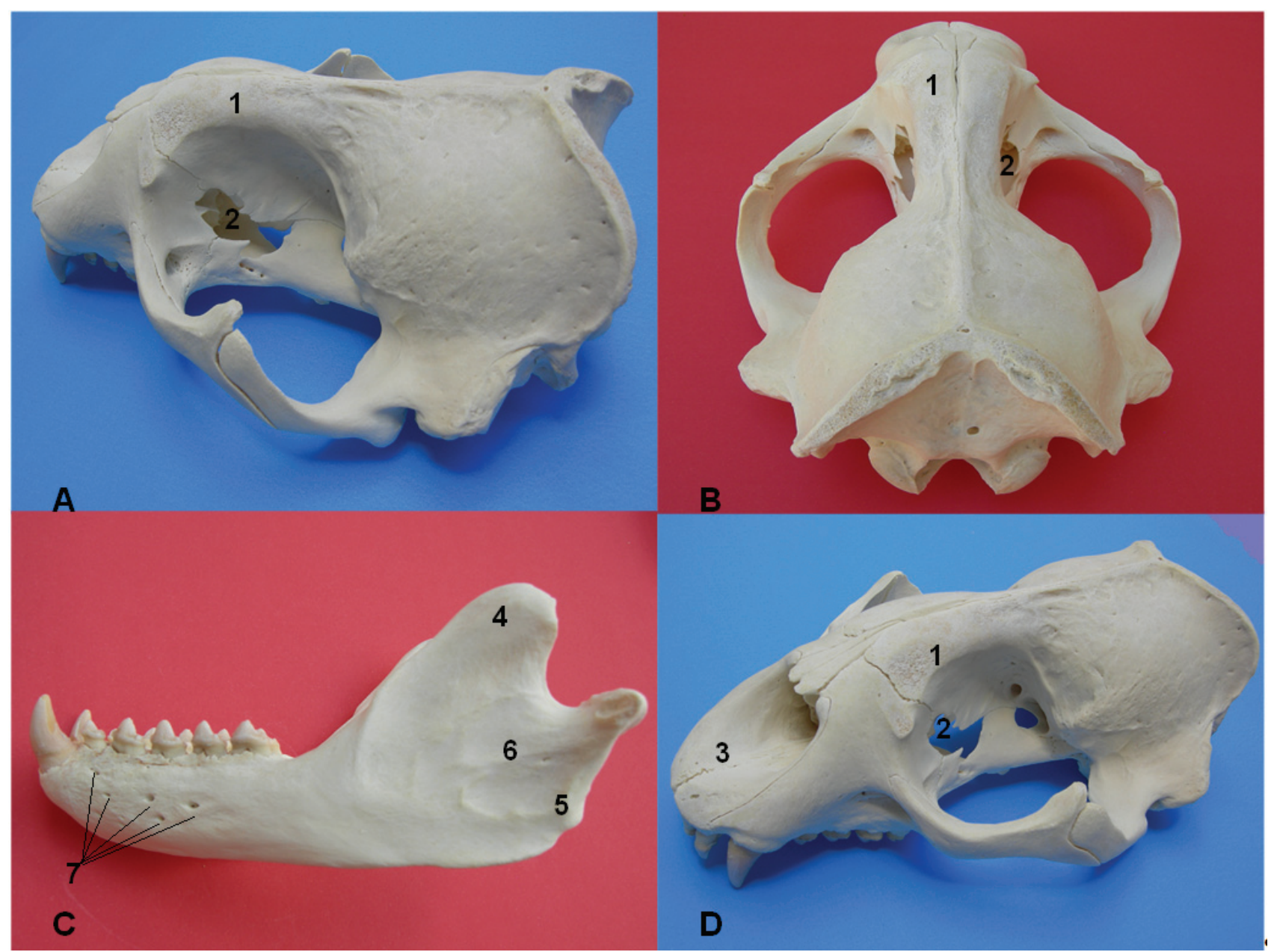

Figure 3. View of the Mediterranean monk seal's cranium and mandible, A. Caudolateral, B. Caudodorsal, C. Lateral mandibular, D. Craniolateral aspect.

1. Frontal bone, 2. Hole in the medial face of orbit, 3. Incisive bone, 4. Coronoid process, 5. Angular process, 6. Masseteric fossa, 7. Mental foramina.

Şekil 3. Akdeniz Foku cranium'unun ve mandibula'sının görünümü, A. Caudolateral, B. Caudodorsal, C. Lateral mandibular, D. Craniolateral görünüm.

1. Os frontale, 2. Orbita'nın medial yüzündeki delik, 3. Os incisivum, 4. Processus coronoideus, 5. Processus angularis, 6. Fossa masseterica, 7. Foramina mentalia. 


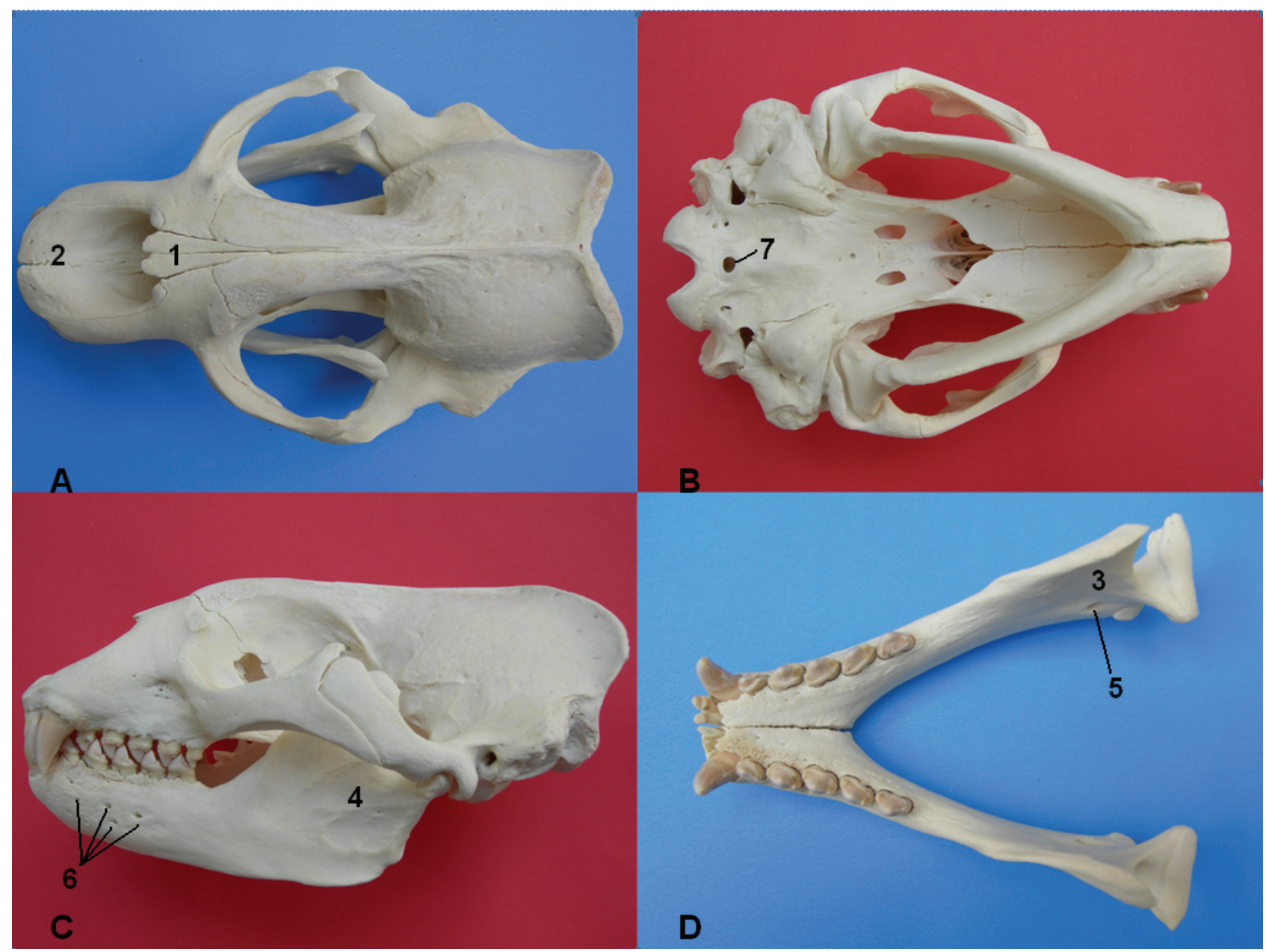

Figure 4. View of the Mediterranean monk seal's cranium (with mandible) and mandible, A. Dorsal, B. Basal, C. Lateral, D. Dorsal mandibular aspect.

1. Nasal bone, 2. Incisive bone, 3. Medial face of coronoid process, 4. Masseteric fossa, 5. Mandibular foramen, 6. Mental foramina, 7. Circular hole at the basal part of occipital condyles.

Şekil 4. Akdeniz Foku cranium'unun (mandibula ile birlikte) ve mandibula'sının görünümü, A. Dorsal, B. Basal, C. Lateral, D. Dorsal mandibular görünüm.

1. Os nasale, 2. Os incisivum, 3. Processus coronoidus'un medial yüzü , 4. Fossa masseterica, 5. Foramen mandibulae, 6. Foramina mentalia, 7.Condylus occipitalis'lerin basal kısmındaki sirküler delik.

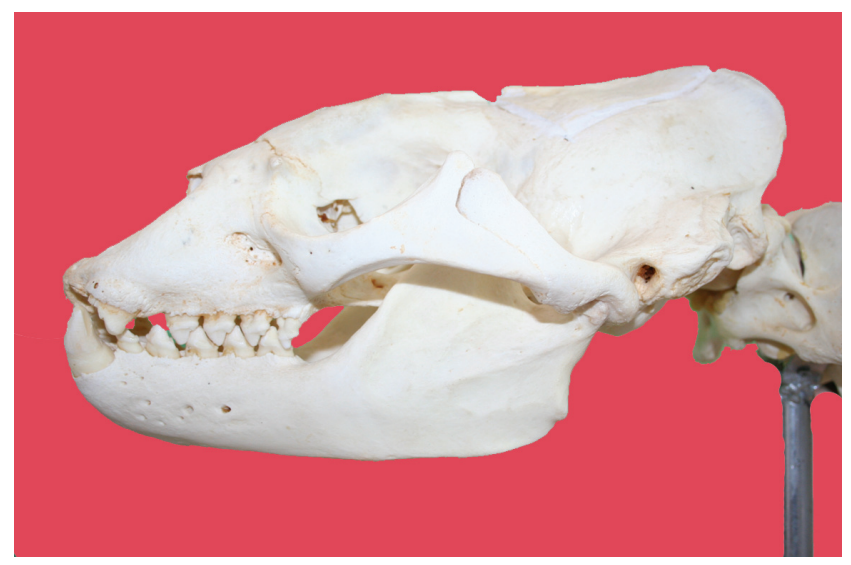

Figure 5. Lateral view of the Mediterranean monk seal's cranium (with mandible).

Şekil 5. Akdeniz Foku cranium'unun (mandibula ile birlikte) lateral'den görünümü.
Temporal process of the zygomatic bone was slightly bifurcated and zygomatic process of the temporal bone was bonded to this bifurcation. As a result of the cranially over extention of frontal bone, the nasal bones were formed short and broadened toward the front (Figure 2.A.5; C.5; Figure 4.A.1). It was detected that the zygomatic arch curved prominently. The distance between the maxillary and the infraorbital foramina was measured as $15 \mathrm{~mm}$. When nasal cavity was examined, it was observed that the nasal conchae were formed from dense, thin layers that fill the entire nasal cavity (Figure 2.C.6). Incisive bone was ended in the front as blunt and this formation affected the structure of mouth (Figure 3.D.3; Figure 4.A.2).

The coronoid process of the mandible was short and thick (Figure 3.C.4) and on the medial face at the back, a prominent cavity was observed (Figure 4.D.3). Angular process was not significant. But it was formed at the 
caudal edge of ramus of the mandible, not on the apex (Figure 3.C.5). The masseteric fossa was not so deep and had linear marks parallel to its long axis (Figure 3.C.6; Figure 4.C.4). Mandibular foramen was observed more inferior (Figure 4.D.5). Also number of mental foramina varied between 4-6 (Figure 3.C.7; Figure 4.C.6). There was no premolar and molar differentiation in both maxillary and mandibular arch and both had 4 incisive, 2 canine and 10 molar teeth (Figure 3.C; Figure 4.D; Figure 5). Thus it was determined that Mediterranean Monk Seal had totally 32 teeth.

\section{Discussion and Conclusion}

Gomercic et al. (15) have indicated some craniometric measurements for the monk seal. They've used 24 parameters in their study and total cranium length was found as $24.77 \mathrm{~cm}$. In the present study, 3 craniums were examined and average length of the craniums was measured as $26.86 \mathrm{~cm}$.

In a study (16), craniometric findings of two years old male Mediterranean Monk Seal lived in Adriatic Sea were revealed. Measurements from 17 points of cranium and mandible were performed and height of the coronoid of mandible was found as $44 \mathrm{~mm}$. In the present study, together with the mandible, totally 46 points were measured and average height of the coronoid was found as $76 \mathrm{~mm}$.

In two different studies $(8,27)$ head of 17 Mediterranean Monk Seals obtained from the museums in Italy were analyzed in terms of the geometric morphometric analysis of the bone shapes and bone density. Thus, it was tried to determine the age and the gender with this methods. The findings of the studies offered limited estimation to the researchers, besides it was expressed that advanced geometric morphometric techniques would be more useful. In the present study the craniums belonged to the animals died in recent years and these animals were registered in detail. Information about the gender and age is available; therefore geometric measurements and bone density measurements were found unnecessary.

Cruwys and Friday (9) measured the condylobasal length of head of 999 adult seal, sea lion and fur seals and it was determined that this length continued to lengthen after reaching to puberty. In the present study condylobasal length of cranium of Mediterranean Monk Seal was measured as $26.96 \mathrm{~cm}$ in average.

As compared to dogs, it was observed that the external sagittal crest was not significant and the parietal bone was more protuberant and wide laterally. The zygomatic arch curved prominently. Besides, the coronoid process of mandible was short and thick similar to dog. The mandibular foramen was observed more inferior as compared to other mammals. As seen on bovidae, the temporal process of the zygomatic bone was slightly bifurcated and the zygomatic process of the temporal bone was bonded to this bifurcation (12).

In a study conducted by Johnson et al. (19), Mediterranean Monk Seals had 4 incisive, 2 canine and 10 molar teeth in both mandibular and maxillar bone. In this study, parallel to the study of Johnson et al. (19), Mediterranean Monk Seal had totally 32 teeth with 4 incisive, 2 canine and 10 molar in both mandibular and maxillar bone.

This study will make a contribution to basic anatomical information about the Mediterranean monk seal, one of the endangered species that lives in Turkish coasts.

\section{References}

1. Adam P J (2004): Monachus tropicalis. Mammalian Species, 747, 1-9.

2. Aguilar A, Lowry L (2008): Monachus monachus. In: IUCN 2010. IUCN Red List of Threatened Species. Version 2010.2.www.iucnredlist.org.

3. Antonio A, Mignucci - Giannoni, Daniel KO (2001): Tropical and Subtropical Records of Hooded Seals (Cystophora cristata) Dispel the Myth of Extant Caribbean Monk Seals (Monachus tropicalis). B Mar Sci, 68, 47-58.

4. Atkinson S, Becker BL, Johanos TC, Pietraszek JR, Kuhn BC (1994): Reproductive morphology and status of female Hawaian monk seals (Monachus schauinslandi) fatally injured by adult male seals. J Reprod Fertil, 100, 225-30.

5. Baker K (2008): Endangered Species Act 5-Year Review, Caribbean Monk Seal (Monachus tropicalis). National Oceanic and Atmospheric Administration National Marine Fisheries Service, 1-19.

6. Baker JD, Thompson PM (2007): Temporal and spatial variation in age-specific survival rates of a long-lived mammal, the Hawaiian monk seal. Proc Biol Sci, 274, 407-15.

7. Berkes F, Anat H, Esenel M, Kışlalıoğlu M (1979): Distribution and ecology of monachus monachus on turkish coasts. In: Ronald $K$ and Duguy $R$, eds. First International Conference on the Mediterranean Monk Seal, Rhodes, Greece, 2-5 May 1978. Pergamon Press, Oxford, UK. UNEP Technical Series 1: 113-128.

8. Brombin C, Mo G, Zotti A, Gurisato M, Salmaso L, Cozzi B (2009): A landmark analysis-based approach to age and sex classification of the skull of the Mediterranean monk seal (Monachus monachus) (Hermann, 1779). Anat Histol Embryol, 38, 382-386.

9. Cruwys E, Friday AE (1995): A comparative review of condylobasal lengths and other craniometric characters in 30 species of pinniped. Polar Record, 31, 45-62.

10. Dennison SE, Schwarz T (2008): Computed tomographic imaging of the normal immature California sea lion head (Zalophus californianus). Vet Radiol Ultrasound 49, 557563.

11. Driesch AVD (1976): Guide to the measurement of animal bones from archaeological sites: As developed by the Institut für Palaeoanatomie, Domestikationsforschung und 
Geschichte der Tiermedizin of the University of Munich, peabody museum bulletein 1. Peabody Museum of Archaeology and Ethnology, Harvard University, pp. 4245 / 60-61.

12. Dyce KM, Sack WO, Wensing CJG (2002): The Locomotor Apparatus. 58-66. In: Textbook of Veterinary Anatomy. Saunders-Elsevier Science, Philadelphia.

13. Endo H, Sasaki H, Hayashi Y, Petrov EA, Amano M, Suzuki N, Miyazaki N (1999): CT examination of the head of the Baikal seal (Phoca sibirica). J Anat, 194, 119126.

14. Endo H, Sasaki H, Hayashi Y, Petrov EA, Amano M, Miyazaki N (1998): Functional relationship between muscles of mastication and the skull with enlarged orbit in the Baikal seal (Phoca sibirica). J Vet Med Sci, 60, 699704.

15. Gomercic T, Farkas V, Gomercic MD, Huber D, Gomercic H (2009): Cranial morphometry of adult Mediterranean monk seal (Monachus monachus) from the Adriatic sea. Proceedings of the international scientific meeting of anatomy and physiology, 120-128, June 1213.2009, Zagreb, Croatia.

16. Gomercic H, Huber D (1989): Craniometric characteristics of the Mediterranean monk seal (Monachus monachus Hermann 1779) from the Adriatic Sea. Period biol, 91, 132.

17. Güçlüsoy H, Kıraç CO, Veryeri NO, Savaş Y (2004): Status of the Mediterranean Monk Seal, Monachus monachus (Hermann, 1779) in the Coastal Waters of Turkey. E.Ü. Journal of Fish \& Aquat Sci, 21, 201-210.

18. Güçlüsoy H, Örek H, Veryeri NO (2003): Is the Rehabilitation of the Mediterranean Monk Seal Monachus monachus (Hermann 1779) In Turkey Necessary. The Monachus Guardian. 6, 1-5.

19. Johnson WM, Karamanlidis AA, Dendrinos P, Larrinoa PF, Gazo M, Gonzales LM, Güçlüsoy H, Pires R, Schnellmann M (2006): Monk Seal Fact Files. Mediterranean monk seal, Monachus monachus. Erişim: http://www.monachus-guardian.org/factfiles/medit01.htm

20. Johnson WM, Lavigne DM (1998): The Mediterranean Monk Seal. Conservation Guidelines. Multilingual Edition. International Marine Mammal Association Inc., Guelph, Ontario, Canada: 1-152.
21. Kıraç CO, Güçlüsoy H (2008): Foça ve Akdeniz Foku, Foça Özel Çevre Koruma Bölgesinde Akdeniz Fokunun (Monachus monachus) korunması ve izlenmesi. 1. bask1, Özel Çevre Koruma Kurumu Başkanlığı.

22. Kıraç CO, Savaş Y, Güçlüsoy H, Veryeri NO (2004): 40 years of Mediterranean Monk Seal Conservation in Turkey. The Monachus Guardian, 7, 2.

23. Kıraç CO, Savaş Y, Güçlüsoy H, Veryeri NO (1998): Status and distribution of monk seal Monachus monachus (Hermann 1779) along Turkish coasts. The World Marine Mammal Science Conference, Workshop on the Biology and Conservation of the World's Endangered Monk Seals, 19-24 January 1998, Monaco.

24. Kompanje EJO, Güçlüsoy H, van Bree PJH (2000): Osteoporosis in an adult female monk seal Monachus monachus from Çeşme, Turkey. The Monachus Guardian, 3, 43-45.

25. Mursaloğlu B (1992): Biology and distribution of the Mediterranean Monk Seal Monachus monachus on Turkish coasts. In: Conservation of the Mediterranean Monk Seal - Technical Aspects, Antalya, Turkey, 1-4 May 1991. Council of Europe, 54-57.

26. Mursaloğlu B (1964): Occurrence of the Monk Seal on the Turkish Coasts. J Mammal, 45, 316-317.

27. Mo G, Zotti A, Agnesi S, Finoia MG, Bernardini D, Cozzi B (2009): Age classes and sex differences in the skull of the Mediterranean monk seal, Monachus monachus (Hermann, 1779). A study based on bone shape and density. Anat Rec (Hoboken), 292, 544-556.

28. Savaş Y (2000): Monk seal behaviour under surveillance. The Monachus Guardian, 3, 28.

29. Toplu N, Aydoğan A, Oğuzoğlu TC (2007): Visceral leishmaniosis and parapoxvirus infection in a Mediterranean monk seal (Monachus monachus). J Comp Pathol, 136, 283-287.

Geliş tarihi: 31.05.2011 / Kabul tarihi: 22.03.2012
Address for correspondence:
Prof.Dr. Ahmet Çakır
Ankara University, Faculty of Veterinary Medicine,
Department of Anatomy,06110-Ankara
e-mail :acakir@ankara.edu.tr 